\title{
Deep water populations of Lobophora variegata (Phaeophyceae) on the coral reef of Curaçao: influence of grazing and dispersal on distribution patterns
}

\author{
E. D. de Ruyter van Steveninck \& A. M. Breeman \\ Department of Marine Biology, University of Groningen, PO Box 14, 9750 AA Haren (Gn), The Netherlands
}

\begin{abstract}
On the coral reef of Curaçao (Netherlands Antilles) the foliose brown macroalga Lobophora variegata (Lamouroux) Womersley displays a discontinuous depth distribution, with distinct belts in the deep algal community (below $30 \mathrm{~m}$ ) and in the eulittoral community. This distribution pattern is attributed to high grazing pressure in the areas devoid of L. variegata, where the alga will survive and grow year-long if protected from sea urchins and herbivorous fish. There was a distinct gradient in grazing pressure decreasing with depth. After the occurrence of mass mortality in the sea urchin Diadema antillarum Philippi, which took place in the course of this study, overall grazing pressure on the alga was reduced. However, this 'natural experiment' did not result in a very marked increase of the depth range of $L$. variegata, probably because the dispersal range of propagules is very limited. Recruitment only occurred within meters of the nearest $L$. variegata stand
\end{abstract}

\section{INTRODUCTION}

Grazing is considered to be the main factor structuring algal communities on coral reefs. Algal vegetation is reduced to inconspicuous turf with low biomass but high productivity, whereas larger macroalgae are restricted to areas with lower grazing pressure (reviews by Ogden \& Lobel 1978, Borowitzka 1981, Gaines \& Lubchenco 1982, Littler \& Littler 1984). This general conclusion disregards the specific abilities of individual algal species to cope with the severe grazing pressure characteristic of coral reefs (Littler \& Littler 1980, Norris \& Fenical 1982, Littler et al. 1983b). Recent grazing studies on coral reef algae have focused on morphological and chemical defense mechanisms (Norris \& Fenical 1982, Littler et al. 1983a, Hay 1984a, Morrison 1986, Paul \& Hay 1986) and on the differential susceptibility and competitive properties of plants growing in various reef zones (Hay 1981a, b, 1984a, Lewis 1985). These studies have shown that there may be large differences in the susceptibility of a single algal species if growing at different locations. Moreover, susceptibility did not always tally with the presence of morphological or chemical characteristics thought to be indicative of herbivore defense mechanisms (Hay 1984a, Lewis 1985).

One species for which contradictory observations on herbivore susceptibility have been reported is the foliose brown macroalga Lobophora variegata (Lamouroux) Womersley. Earle (1972), Brawley \& Adey (1977), Hay (1984a) and Lewis (1985) found that this species is grazed, but according to Morrison (1984, 1986) L. variegata is consumed only by sea urchins (Diadema sp.) and not by parrot fish (Sparisoma sp.). No substantial grazing on $L$. variegata was observed by Hay (1981b) and Norris \& Fenical (1982), although no chemical defense mechanisms could be detected (Norris \& Fenical 1982). However, more recently, Paul \& Hay (1986) correlated the low susceptibility of $L$. variegata to herbivory with the presence of secondary metabolites. Littler et al. (1983a) consider certain morphological characteristics of $L$. variegata, i.e. its thick leathery form, as the defense mechanism against herbivory.

At Curaçao, van den Hoek et al. (1978) reported Lobophora variegata from 2 distinct belts, one in the 
eulittoral community, the other in the deep algal community (below $30 \mathrm{~m}$ ). They attributed this discontinuous distribution pattern to intensive grazing in the reef zones devoid of $L$. variegata. To test this hypothesis, and to gain a broader insight into temporal and spatial distribution patterns of this common reef alga, an extensive study on $L$. variegata was initiated on the coral reef of Curaçao.

de Ruyter van Steveninck \& Breeman (1987) studied population dynamics in 2 deep water populations of Lobophora variegata, which differed strongly in L. variegata cover and in the density of the herbivorous sea urchin Diadema antillarum Philippi. In the course of the study, in October 1983, mass mortality in the $D$. antillarum population reduced $D$. antillarum densities to less than $5 \%$ of the original levels (Bak et al. 1984, de Ruyter van Steveninck \& Bak 1986). This resulted in an increase in $L$. variegata cover and blade size at the location where pre-mortality $D$. antillarum densities had been highest, suggesting that differences in grazing pressure had caused the original differences in $L$. variegata cover at the 2 locations (de Ruyter van Steveninck \& Breeman 1987). Turnover rates of $L$. variegata blades were high (half-lives of 9 to $39 \mathrm{~d}$ ), also suggesting that grazing is an important structuring force in L. variegata populations (de Ruyter vân Steveninck \& Breeman 1987).

In the present study transplantation experiments were carried out to examine the effect of grazing on deep water populations of Lobophora variegata, and to test the ability of this species to survive and grow in reef zones where it is otherwise absent. In addition, propagation and recruitment of $L$. variegata in various reef zones was investigated. Some experiments were carried out before Diadema antillarum mass mortality took place, some were in progress when mass mortality occurred, and others were carried out after the event, when $D$. antillarum remained virtually absent from the reef for at least 2 yr (de Ruyter van Steveninck \& Bak 1986).

\section{MATERIAL AND METHODS}

Location. This study was carried out on the coral reef off the leeward southwest coast of Curaçao (Netherlands Antilles). For a general description of the area see van den Hoek et al. (1975). In February 1983, 2 locations were selected which were seen to differ greatly in Lobophora variegata cover and in the density of the herbivorous sea urchin Diadema antillarum (de Ruyter van Steveninck \& Breeman 1987): (1) the reef in front of the Holiday Beach hotel ( $\mathrm{HB})$, with a dense L. variegata vegetation consisting of large frondose plants extending from $20 \mathrm{~m}$ depth downward and high $D$. antillarum densities occurring at shallow depths only (Table 1); and (2) the reef in front of Klein Piscadera, CARMABI Buoy 1 (B1), with a sparse $L$. variegata vegetation consisting of small, more or less crustose plants extending no higher than $25 \mathrm{~m}$ depth and high $D$. antillarum densities down to a depth of 12 to $20 \mathrm{~m}$ (Table 1). This was before the occurrence of mass mortality in the $D$. antillarum population, which took place in October 1983 (Bak et al. 1984, de Ruyter van Steveninck \& Bak 1986). Ail through 1984 and 1985 D. antillarum remained virtually absent from the coral reef of Curaçao (Table 1).

Grazing and survival experiments. A comparison of grazing pressure on Lobophora variegata at different depths was made before (March to June 1983) and after (March 1985) the mass mortality in Diadema antillarum. For this purpose, limestone substrata (90 to $300 \mathrm{~cm}^{2}$ ), with the attached $L$. variegata vegetation, were sampled near Holiday Beach at $25 \mathrm{~m}$ depth, and transplanted to 3,12 and $25 \mathrm{~m}$ depth at Holiday Beach (HB) and Buoy 1 (B1) (1983) or to 12 and $25 \mathrm{~m}, \mathrm{~B} 1$ (1985). The limestone substrata were collected using hammer and chisel and were transported to the laboratory, where they were kept in running seawater for no more than $24 \mathrm{~h}$. A hole was drilled through the limestone and the transplants were fixed at the experimental sites in random positions using steel nails.

Table 1. Diadema antillarum (D. a.) and Lobophora variegata (L.V.). Occurrence at various depths at 2 locations before and after $D$. antillarum mass mortality in October $1983:+++$, abundant ${ }_{i}+$, patchy $(\text { L. V.) })_{i}+$, present; - , absent. Based on visual estimation and quantitative data for selected depths from Bak et al. (1984), de Ruyter van Steveninck \& Bak (1986) and de Ruyter van Steveninck \& Breeman (1987)

\begin{tabular}{|c|c|c|c|c|c|c|c|c|}
\hline \multirow[t]{3}{*}{ Depth $(\mathrm{m})$} & \multicolumn{4}{|c|}{ Before mortality } & \multicolumn{4}{|c|}{2 yr after mortality } \\
\hline & \multicolumn{2}{|c|}{ Holiday Beach } & \multicolumn{2}{|c|}{ CARMABI BUOY 1} & \multicolumn{2}{|c|}{ Holiday Beach } & \multicolumn{2}{|c|}{ CARMABI Buoy 1} \\
\hline & D. a. & L.V. & D.a. & L.V. & D. a. & L.V. & D. $a$. & L. $V$. \\
\hline 5 & $+t+$ & - & $++t$ & - & - & - & - & - \\
\hline 12 & + & - & +++ & - & - & + & - & - \\
\hline 20 & - & +++ & + & - & - & +++ & - & - \\
\hline 25 & - & +++ & + & + & - & $+t+$ & - & ++ \\
\hline 30 & - & +++ & + & + & - & +++ & - & ++ \\
\hline 35 & & & - & ++ & & & - & ++ \\
\hline
\end{tabular}


Transplants placed back at HB $25 \mathrm{~m}$ and transplants placed inside cages (mesh size $12 \times 12 \mathrm{~mm}$ ) at ali experimental depths served as controls. L. variegata cover was estimated visually, immediately after the transplants had been placed on the reef and again after $24 \mathrm{~h}$, after which time the percentage of L. variegata lost over this period was calculated.

As these short-term experiments do not take account of the possibility that Lobophora variegata may be unable to survive and grow in reef zones where it is otherwise absent, a long-term experiment was started in June 1983 in order to assess the survival potential of $L$. variegata at various depths if plants were protected from grazers. For this purpose, limestone substrata (40 to $200 \mathrm{~cm}^{2}$ ) with the attached $L$. variegata vegetation were placed on the reef elevated from the bottom on a $35 \mathrm{~cm}$ long iron pin and covered with a wire netting roof (mesh size $24 \times 24 \mathrm{~mm}$ ) to eliminate sea urchin and fish grazing. Transplants were placed at B1 at 3, 12,25 and $35 \mathrm{~m}$ depth. At the latter 2 depths, where $L$. variegata reaches low to medium densities, respectively, non-caged control transplants were added to check for a possible cage-effect on $L$. variegata survival. All material for the transplants was collected near HB $25 \mathrm{~m}$. After some time, it became clear that the construction of the roofs allowed fish to graze on $L$. variegata along the edges of the transplants. Therefore, in February 1984, the roofs were improved with wire netting rims along the sides, which resuited in bottomless cages hanging over the transplants. L. variegata cover was estimated visually, immediately after the transplants had been placed on the reef and again after $5 \mathrm{~d}$. Thereafter, $L$. variegata cover was estimated at monthly intervals until August 1984 (15 mo)

In a final series of experiments, blade size, growth rate and longevity of individual Lobophora variegata blades were measured in caged and non-caged plants that had been incubated at different depths in the reef for a period of 3 mo. The experiment was started in December 1984, when substrata with L. variegata were sampled at $\mathrm{HB}$ and at $\mathrm{B} 1$ at $30 \mathrm{~m}$ depth. They were transported in seawater to the laboratory where they were mounted on grids using plastic-covered wire. Thereafter they were transferred to their original location where they were placed at 12 or $30 \mathrm{~m}$ depth either inside or outside cages (mesh size $12 \times 12 \mathrm{~mm}$ ). Blade size, growth rate and longevity of the $L$. variegata blades were estimated using a photographic method (de Ruyter van Steveninck \& Breeman 1987). Blade size (measured as 'radius' in mm; de Ruyter van Steveninck \& Breeman 1987) was established immediately after the transplants had been placed on the reef, and again 3 mo later for 15 to 40 randomly chosen blades. Growth rates (Specific Growth Rate, measured as the increase in 'radius' and expressed as percentage increase per day; de Ruyter van Steveninck \& Breeman 1987) were measured in blades with intact margins in order to compare the maximal growth potential under various conditions. Growth was determined over the first 2 wk of incubation for 7 to 17 randomly chosen blades. Longevity was estimated for 10 to 20 randomly chosen blades. Their persistence was checked after $24 \mathrm{~h}, 48 \mathrm{~h}$, $1 \mathrm{wk}, 2 \mathrm{wk}$, and subsequently once per fortnight. Depletion curves were constructed from which halflives were calculated (Harper 1977)

Dispersal. The dispersal potential of Lobophora variegata was assessed by comparing colonization success at sites varying in distance to the nearest $L$. variegata stand. For this purpose, colonization was measured in a dense $L$. variegata vegetation, in an open, patchy $L$. variegata vegetation, and at a series of depths at ever increasing distance from the deep water L. variegata populations. In some cases substrata to be colonized were protected against grazing.

Colonization in a relatively dense Lobophora variegata vegetation was studied in permanent quadrats (16 $\times 11.5 \mathrm{~cm} ; \mathrm{HB}, 25$ to $30 \mathrm{~m}$ ), which were cleared of all macroscopic vegetation with a wire-brush in February $(n=4)$ or August $(n=5) 1983$ in order to find a possible effect of season. The quadrats were photographed at 2 to 4 wk intervals (cf. de Ruyter van Steveninck \& Breeman 1987) until $L$. variegata had recovered its original density.

Colonization in a patchy Lobophora variegata vegetation was studied by comparing colonization success inside and outside $L$. variegata patches. For this purpose perspex plates $(10 \times 10 \mathrm{~cm})$, roughened with sandpaper, were placed inside $(n=10)$ and outside $(\mathrm{n}=7$ ) L. variegata patches at $30 \mathrm{~m}$ depth at $\mathrm{B} 1$ in December 1984. Each month, until December 1985, L. variegata cover on these substrata was estimated visually and the way in which colonization had occurred was noted (i.e. by settlement of spores or vegetative fragments or by overgrowth over the edges of the plates by neighbouring $L$. variegata plants).

To obtain an impression of recruitment of Lobophora variegata in various depth zones 2 types of substrata were used: limestone slabs (100 to $\left.200 \mathrm{~cm}^{2}\right)$, sawn out of coral colonies (Montastrea annularis [Ellis et Solander]) and perspex plates $(10 \times 10 \mathrm{~cm})$, roughened with sandpaper. The limestone slabs were placed in the reef at 3,12 and $25 \mathrm{~m}$ ( $\mathrm{HB}$ and $\mathrm{B} 1$ ) and at $35 \mathrm{~m}$ (B1) in June 1983. At each site 15 slabs were placed (see 'Results' for exact numbers, as some substrata were lost), 5 of which were protected against fish and urchin grazing by placing them on a $35 \mathrm{~cm}$ long pin and covering them with a wire netting roof (mesh size $24 \times 24 \mathrm{~mm}$ ). Each month, until August 1984, the presence of L. variegata on these substrata was checked and the way in which colonization had occurred was noted. 
The perspex plates were placed in the reef at 12 and $30 \mathrm{~m}$ depth (HB and B1) in December 1984. At each site 10 plates were placed at the reef bottom without any protection against grazers, 10 others were put in cages (mesh size $12 \times 12 \mathrm{~mm}$ ) to exclude grazing (see 'Results' for exact numbers, as some plates were lost). Presence of $L$. variegata and the way in which colonization occurred was checked each month until October 1985.

\section{RESULTS}

\section{Grazing and survival}

Before Diadema antillarum mass mortality Lobophora variegata transplants incubated at Holiday Beach ( 3 and $12 \mathrm{~m}$ ) and at Buoy 1 (3, 12 and $25 \mathrm{~m}$ ) showed significant losses (25 to $72 \%$ ) within $24 \mathrm{~h}$ when compared to controls incubated at HB $25 \mathrm{~m}$ (6\% lost; Fig. 1). Since cover of $L$. variegata within cages did not

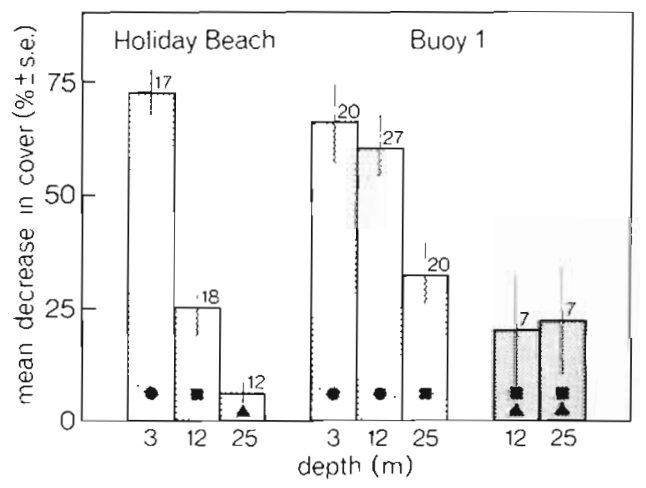

Fig. 1. Lobophora variegata. Grazing losses of transplants incubated at 2 locations and 3 depths before (light bars; March to June 1983) and after (dark bars; March 1985) Diadema antillarum mass mortality. Transplants were collected at Holiday Beach $25 \mathrm{~m}$. Decrease in L. variegata cover was measured after $24 \mathrm{~h}$. Similar symbols within bars indicate no significant difference $(p>0.05)$; different symbols are significant at the $p<0.05$ level (Mann-Whitney $U$ tests); numbers indicate sample size

change, these losses are attributed to grazing. Grazing pressure decreased significantly with depth at $\mathrm{HB}$. At B1 grazing pressure on L. variegata was similar at 3 and $12 \mathrm{~m}$ where it was significantly higher than at $25 \mathrm{~m}$. Differences between $\mathrm{HB}$ and B1 were not significant at depths with comparable $D$. antillarum densities and $L$. variegata cover ( $\mathrm{HB} 3 \mathrm{~m} / \mathrm{B} 13$ and $12 \mathrm{~m}$; $\mathrm{HB}$ $12 \mathrm{~m} / \mathrm{B} 125 \mathrm{~m}$; Fig. 1, Table 1), but were significant at other depths. Thus, expected herbivore damage to $L$. variegata correlated positively with densities of $D$. antillarum in the various reef zones and was inversely related with L. variegata cover. After D. antillarum mortality, grazing pressure on $L$. variegata was reduced significantly at B1 $12 \mathrm{~m}$, where it was no longer significantly different from that at $25 \mathrm{~m}$. The initial differences in grazing pressure between $\mathrm{HB}$ and B1 had disappeared 1.5 yr after $D$. antillarum mortality, reflecting the absence of $D$. antillarum at both sites.

Survival potential of Lobophora variegata at different depths was investigated in a long-term experiment. At all depths caged $L$. variegata survived for the entire experimental period of 15 mo (Fig. 2). It was also capable of growth at all depths as is shown by the occasional increase in cover at all sites (Fig. 2). At the greatest depths (25 and $35 \mathrm{~m}$ ), where $L$. variegata occurs at low to medium densities, cover remained
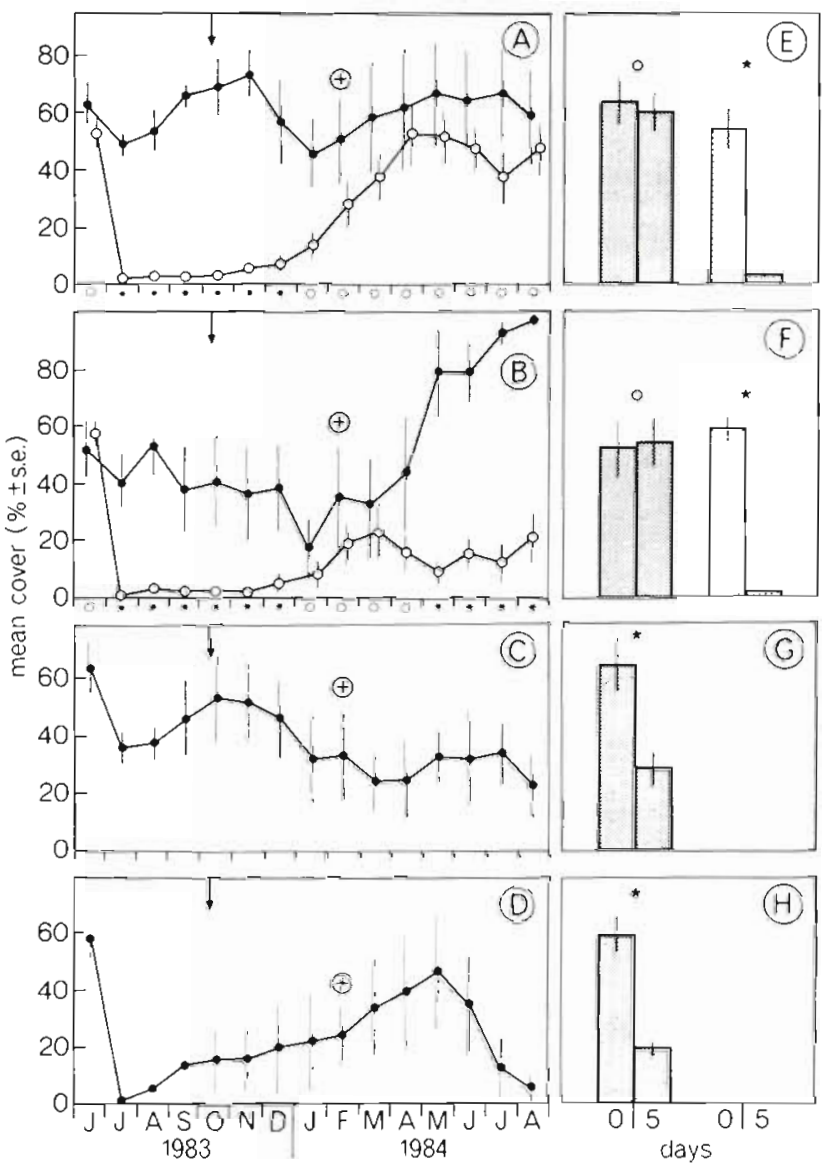

Fig. 2. Lobophora variegata. (A to D). Survival potential of caged and non-caged transplants incubated at various depths at Buoy 1. Transplants were collected at Holiday Beach $25 \mathrm{~m}$. Caged transplants $(\bullet ; n=5)$ were incubated at (A) $35 \mathrm{~m}$, (B) $25 \mathrm{~m}$, (C) $12 \mathrm{~m}$, and (D) $3 \mathrm{~m}$; non-caged transplants (O) at (A) $35 \mathrm{~m}(\mathrm{n}=7)$, and (B) $25 \mathrm{~m}(\mathrm{n}=10)$. Significant differences between treatments (caged $v 5$ non-caged) shown on abscissa $\left(A_{1}, B_{i} \text { Mann-Whitney U tests: }=p<0.05 ; o=p>0.05, n s\right)_{i}$ arrow: Diadema antillarum mass mortality in October 1983; $(\oplus)$ wire netting roofs were improved for further reduction of fish grazing. ( $\mathrm{E}$ to $\mathrm{H}$ ). Changes in cover during the initial $5 \mathrm{~d}$ of the experiment for caged (dark bars) and non-caged (light bars) transplants. Significant reduction in cover shown above bar diagrams (t-test for paired comparisons: ${ }^{*}=p<0.05 ; 0=$ $\mathrm{p}>0.05, \mathrm{~ns})$ 
relatively constant and it even increased at $25 \mathrm{~m}$ after the improvement of the cages for better protection against grazing fish (Fig. 2 B). In contrast, at shallower depths ( 3 and $12 \mathrm{~m}$ ) cover decreased in the protected transplants, both as a short-term effect directly after transplantation (Fig. $2 \mathrm{G}, \mathrm{H}$ ) and in the long run (Fig. 2C, D), because cover never attained its original level. Evidently, adverse physical factors such as strong surf at $3 \mathrm{~m}$ and high sedimentation at the reef flat, or small grazers entering the cages, kept cover values at these depths below the original level.

At 25 and $35 \mathrm{~m}$ non-caged control transplants were rapidly consumed (Fig. $2 E, F$ ) in spite of the fact that Lobophora variegata normally does occur at these depths. However, the L. variegata plants in the transplants (from $\mathrm{HB}$ ) were larger than those in the natural population and thus may have attracted more attention from grazing fish. In these uncaged transplants cover started to increase again directly after Diadema antillarum mortality in October 1983 (Fig. 2 A, B). At 35 m cover was no longer significantly different in caged and non-caged transplants from February 1984, indicating that after $D$. antillarum mortality grazing cannot be considered a limiting factor for $L$. variegata at this depth. At $25 \mathrm{~m}$ cover also started to increase after $D$. antillarum mortality, but there it remained below that in the cages as well as below that found at the start of the experiments in the transplants. Therefore, even after $D$. antillarum mortality, grazing can be considered limiting to $L$. variegata at this depth.

The effect of grazing on the abundance of Lobophora variegata being evident, the influence of grazing on some population characteristics was investigated ca 1 yr after Diadema antillarum mortality. After 3 mo incubation, mean blade size of $L$. variegata was significantly higher inside than outside cages at both 12 and $30 \mathrm{~m}$ depth at both locations (Fig. 3). These differences are attributed to differences in longevity of the blades and not to differences in growth rates. Half-lives inside cages were much higher than outside cages (Table 2), but growth rates of intact blades inside cages were comparable with those found in the natural vegetation at $30 \mathrm{~m}$ depth (Table 3 ). The large difference in halflives inside cages between $\mathrm{HB}$ and $\mathrm{B} 1$ may be a conse-

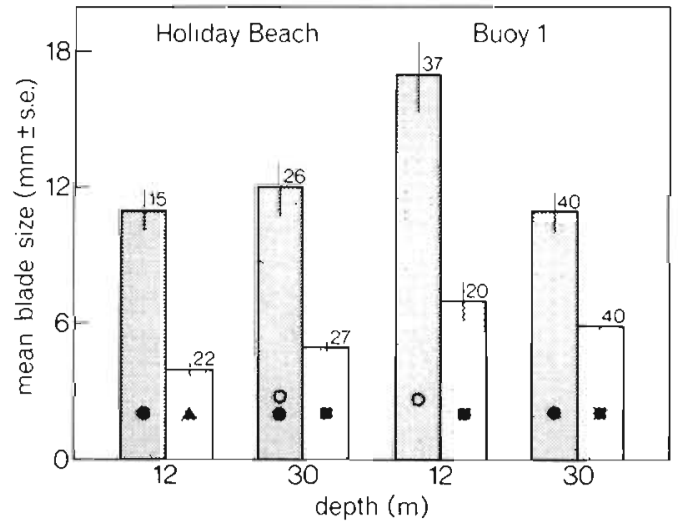

Fig. 3. Lobophora variegata. Effect of grazing on blade size of transplants at 2 locations and 2 depths. Transplants were collected at $30 \mathrm{~m}$ depth at both locations. Mean initial blade size was $8.04 \mathrm{~mm} \pm 4.45$ (SD), $\mathrm{n}=226$. After 3 mo incubation mean blade size was again determined in caged (dark bars) and non-caged (light bars) transplants. Significant differences between treatments, locations and depths are indicated by different symbols within bars $(p<0.05 ; 1$-way ANOVA on logtransformed data); numbers indicate sample size

Table 2. Lobophora variegata. Longevity (as half-lives in d) of blades inside and outside cages at 2 locations and 2 depths. Half-lives were calculated from depletion curves. Number of blades at $\mathrm{t}=0$ in brackets

\begin{tabular}{|llllll|}
\hline \multirow{2}{*}{ Location } & \multicolumn{2}{c}{$12 \mathrm{~m}$} & \multicolumn{2}{c|}{$30 \mathrm{~m}$} \\
& Cage & Open & \multicolumn{2}{c|}{ Cage } & Open \\
\hline $\begin{array}{l}\text { Holiday Beach } \\
\text { Buoy 1 }\end{array}$ & $(10) 44$ & (16) 6 & $(15) 37$ & $(20) 4$ \\
$(20) 103$ & $(20) 6$ & $(20) 170$ & $(20) 5$ \\
\hline
\end{tabular}

quence of high sedimentation at $H B$, which was particularly conspicuous inside cages. However, small differences in growth rates (Table 3 ) could, in the long run, significantly affect blade size, and this may be the cause of some of the significant differences in blade size in the caged transplants at the various sites (Fig. 3). More important is the fact that, at both locations and depths, differences in blade sizes between caged and non-caged transplants are all in the same order of magnitude. About 1 yr after D. antillarum mortality, grazing seems to have much the same effect on $L$.

Table 3. Lobophora variegata. Comparison of growth rates of intact blades in caged transplants and in natural vegetations at 2 locations. Mean specific growth rate (SGR; \% $\mathrm{d}^{-1}$ ) (SD) inside cages at 12 and $30 \mathrm{~m}$ depth are compared with ranges of growth rates found in natural populations at $30 \mathrm{~m}$ depth (de Ruyter van Steveninck \& Breeman 1987). $\mathrm{n}$ : number of blades

\begin{tabular}{|c|c|c|c|c|c|}
\hline \multirow[t]{3}{*}{ Location } & \multicolumn{4}{|c|}{ Cage } & \multirow{3}{*}{$\begin{array}{c}\text { Natural } \\
30 \mathrm{~m}\end{array}$} \\
\hline & \multicolumn{2}{|c|}{$12 \mathrm{~m}$} & \multicolumn{2}{|c|}{$30 \mathrm{~m}$} & \\
\hline & n & SGR & n & SGR & \\
\hline Holiday Beach & 7 & $2.4(0.7)$ & 12 & $2.9(1.7)$ & $1.97(1.02)-2.59(0.67)$ \\
\hline Buoy 1 & 17 & $3.1(1.8)$ & 17 & $2.1(1.1)$ & $1.73(1.37)-3.46(2.06)$ \\
\hline
\end{tabular}


variegata at 12 and $30 \mathrm{~m}$ depth as was also evident from the short-term grazing experiments (Fig. 1), whereas before $D$. antillarum mortality grazing pressure at $12 \mathrm{~m}$ had been markedly higher than at $25 \mathrm{~m}$ (Fig. 1).

\section{Dispersal}

Dispersal potential was assessed by determining colonization success at various distances from existing Lobophora variegata stands. Colonization in a dense $L$. variegata vegetation was studied in permanent quadrats which were cleared of all macroscopic vegetation. The clearings had regained their initial L. variegata cover within 5 to 7 mo and there was no significant difference between seasons with respect to recovery rates (Fig. 4). Recolonization occurred mainly by over-

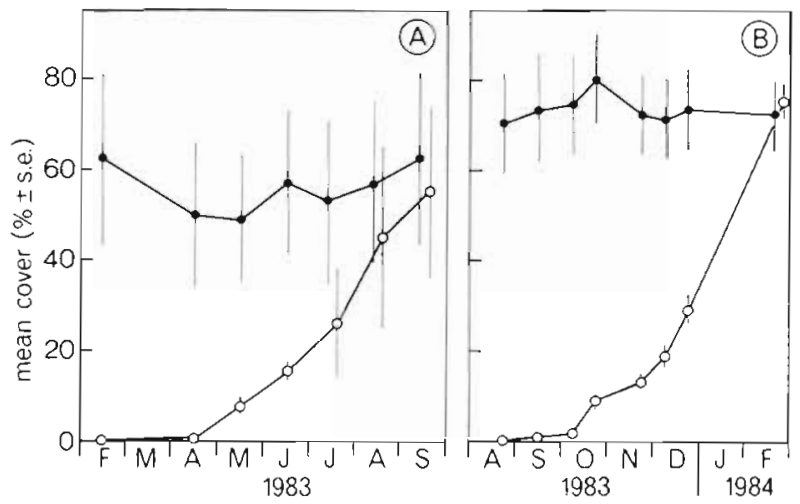

Fig. 4. Lobophora variegata. Recolonization of cleared areas in a dense vegetation. Clearance was done (A) in winter, and (B) in summer. Cover in cleared $(0)$ and non-cleared ( $\bullet$ permanent quadrats $(16 \times 11.5 \mathrm{~cm})$ was measured $(A)$ between February and September $1983(n=4)$, and $(B)$ between August 1983 and February $1984(\mathrm{n}=5)$ at Holiday Beach, 25 to $30 \mathrm{~m}$ depth

growth from established $L$. variegata plants growing at the margins of the clearings. Settlement of spores inside the clearings was almost never observed even though clearance was done in 2 different seasons and reproductive $L$. variegata plants were present at this location all year round (de Ruyter van Steveninck \& Breeman 1987).

Comparison of colonization success of Lobophora variegata in and outside established $L$. variegata patches showed that colonization predominantly occurred within the $L$. variegata patches, mainly by overgrowth through established neighbouring $L$. variegata plants (Fig. 5B). Settlement of a spore or fragment was observed only once. Plates placed outside the established $L$. variegata patches were colonized in only 2 out of 7 cases (Fig. 5B). Besides settlement of a spore or vegetative fragment on one of them, both plates were
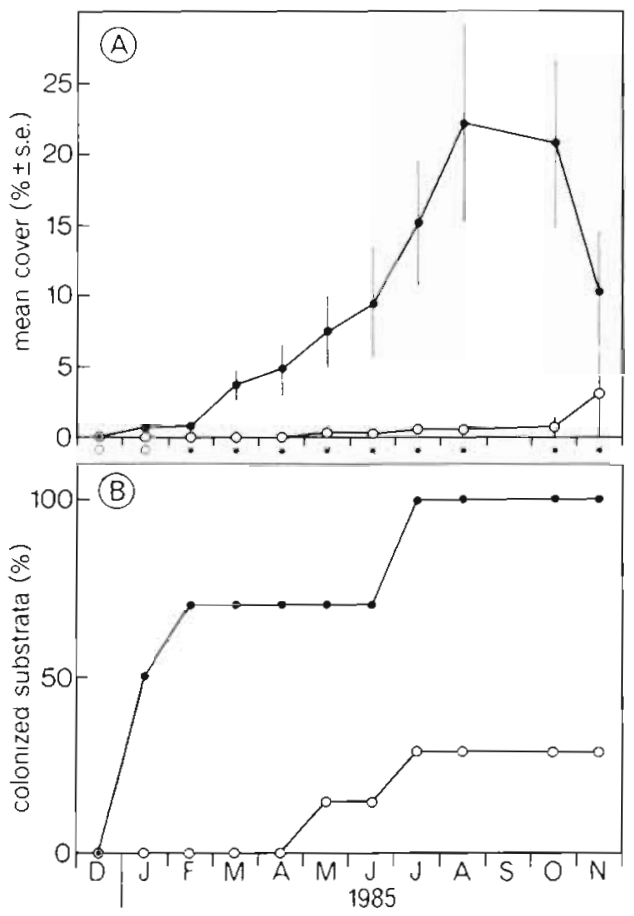

Fig. 5. Lobophora variegata. Comparison of colonization success inside $(\bullet)$ and outside (O) established $L$. variegata patches in an open, patchy $L$. variegata vegetation. Perspex plates $(10 \times 10 \mathrm{~cm})$ were placed inside $(\mathrm{n}=10)$ and outside $(\mathrm{n}=7$ ) L. variegata patches at Buoy $1,30 \mathrm{~m}$ depth. (A) Cover of $L$. variegata on plates. Results of statistical comparison indicated (abscissa): ${ }^{*}=p<0.05 ; 0=p>0.05$, ns (MannWhitney $U$ tests). (B) percentage of colonized plates

colonized by overgrowth of adjacent $L$. variegata plants which, in the course of the experiment, had expanded in the direction of the plates, reaching them during the experimental period. Starting 3 mo after the beginning of the experiment, mean cover was significantly higher on plates within L. variegata patches than on those placed outside the patches (Fig. $5 \mathrm{~A}$ ). The reason for the decrease after August 1985 is not clear, but may be a result of cover having reached a level high enough to attract grazing fish.

Settlement of Lobophora variegata in various depthzones at ever increasing distance from the deep water L. variegata vegetation was very limited. As there was no difference between grazed and non-grazed substrata the results of both treatments are combined (Table 4; Fig. 6). Between June 1983 and August 1984, L. variegata only colonized limestone substrata at depths where it occurred naturally and frequency of colonization decreased with $L$. variegata cover in the various reef zones (Tables 1 \& 4). Between December 1984 and October 1985, the same trend was observed on the perspex plates, although now L. variegata was also observed at $15 \mathrm{~m}$ at B1 (Table 4). Combining the results of both experiments (Fig. 6) the distinct positive 
Table 4. Lobophora variegata. Colonization success at various depths at 2 locations. Number of substrata colonized between June 1983 and August 1984 (limestone slabs, 100 to $200 \mathrm{~cm}^{2}$ ) and between December 1984 and October 1985 (perspex plates, $100 \mathrm{~cm}^{2}$ ); $\mathrm{n}$, number of substrata available. Method of colonization: $\mathrm{s}$, settlement by spore or vegetative fragment; $g$, overgrowth by established $L$. variegata plants bordering the substratum; ?, method unknown; $T$, total number of colonized substrata

\begin{tabular}{|c|c|c|c|c|c|c|c|c|c|c|c|}
\hline \multirow[t]{2}{*}{ Location } & \multirow[t]{2}{*}{ Depth (m) } & \multicolumn{5}{|c|}{ Jun $83-$ Aug 84} & \multicolumn{5}{|c|}{ Dec $84-$ Oct 85} \\
\hline & & $\mathrm{n}$ & $\mathrm{s}$ & $g$ & $?$ & $\mathrm{~T}$ & $n$ & s & $g$ & $?$ & $\mathrm{~T}$ \\
\hline \multirow[t]{3}{*}{ Holiday Beach } & $25-30$ & 13 & 8 & 0 & 3 & 11 & 18 & 0 & 4 & 1 & 5 \\
\hline & $12-15$ & 14 & 3 & 0 & 0 & 3 & 18 & 1 & 2 & 0 & 3 \\
\hline & 3 & $13 / 6^{\circ}$ & & & & 0 & nd & & & & \\
\hline \multirow[t]{4}{*}{ Buoy 1} & 36 & 15 & 4 & 0 & 2 & 6 & nd & & & & \\
\hline & $25-30$ & 15 & 2 & 0 & 0 & 2 & 20 & 2 & 1 & 0 & 3 \\
\hline & $12-15$ & 15 & & & & 0 & 19 & 1 & 0 & 1 & 2 \\
\hline & 3 & 13 & & & & 0 & nd & & & & \\
\hline \multicolumn{12}{|c|}{$\begin{array}{l}\text { n decreased from } 13 \text { (Jun 83) to } 6 \text { (Aug 84) } \\
\text { nd: no data }\end{array}$} \\
\hline
\end{tabular}

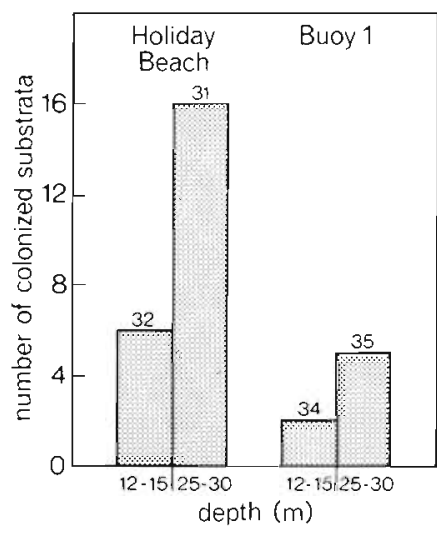

Fig. 6. Lobophora variegata. Colonization success at 12 to $15 \mathrm{~m}$ and 25 to $30 \mathrm{~m}$ depth at 2 locations. Total number of substrata colonized (limestone or perspex) between June 1983 and October 1985. Combined results for 2 substratum types obtained from Table 4 . Numbers indicate number of substrata available

correlation between colonization success and the occurrence of an established $L$. variegata vegetation (Table 1) in the various reef zones is evident.

\section{DISCUSSION}

Based on an interpretation of changes in cover and blade size of the foliose brown macroalga Lobophora variegata, following mass mortality of the herbivorous sea urchin Diadema antillarum, de Ruyter van Steveninck \& Breeman (1987) suggested that grazing greatly influenced distribution and vegetation structure of $L$. variegata on the coral reef of Curaçao. This suggestion is now supported by experimental evidence.
The present study confirms the susceptibility of Lobophora variegata to herbivory in the coral reef of Curaçao, although actual herbivore damage varied with site. Consumption of L. variegata before Diadema antillarum mass mortality decreased with depth, in accordance with the expectation for not heavily overfished reefs (Hay 1984b). Consumption correlated negatively with $L$. variegata cover in the various reef zones, which in turn was negatively related to $D$. antillarum densities (Fig. $1 \& 2$; Table 1). These findings are in contrast with the conclusion of Hay (1981b) that deep reef algae are selected for grazing resistance. He found that various algal species sampled from the deep reef slope at Carrie Bow Cay (ca $30 \mathrm{~m}$ depth), among them $L$. variegata, showed little or no grazing losses within $24 \mathrm{~h}$ of transplantation to the shallow back reef, an area with higher densities of herbivorous fishes and sea urchins (Hay 1981b). However, as stated in the introduction, there are several contradictory observations on the susceptibility of $L$. variegata to various grazers. Which algae are eaten by which herbivores and in what quantity probably depends on an interaction of various factors, for instance food quality, location, presence of toxins or digestibility reducers and the probability of the herbivores being attacked by their own predators while feeding (various authors, cited in Hay 1984a). Lewis (1985) suggested geographical, habitat or individual variation in plant defense mechanisms and/or differences in herbivore guild composition as the factors responsible for variations in algal susceptibility. The importance of the feeding preferences of herbivores on population and community phenomena has been stressed by Lubchenco \& Gaines (1981).

The present study shows that careful interpretation of short-term grazing experiments is essential when trying to explain distribution patterns of reef algae. The 
remarkably high consumption of Lobophora variegata at $35 \mathrm{~m}$ at Buoy 1 (Fig. $2 \mathrm{~A}$ ), where L. variegata occurs naturally in medium densities, may have been caused by the greater attractivity of the large, foliose plants transplanted from Holiday Beach, compared with the smaller and more crustose blades present in the natural population at B1. A newly introduced species or, as in the present case, a different growth form, is probably more attractive to visual grazers, thus biasing the results of grazing experiments (Randall 1961, Wanders 1977). That this may be in fact the case, even with plants transplanted back to their original location, is clear if half-lives and blade sizes from the present study are compared with those in natural populations (de Ruyter van Steveninck \& Breeman 1987). Transplants had shorter life spans and smaller blade sizes, possibly because they attracted more attention from visually orientated grazers and were, in consequence, more heavily grazed. Also the fact that, in short-term experiments, grazing on $L$. variegata transplants placed in a dense $L$. variegata vegetation was low (HB 25 m; Fig. 1) does not preclude a significant influence of grazing on the community. In view of the presence of abundant $L$. variegata in the neighbouring vegetation, low consumption was in fact to be expected in short-term experiments but the high turnover rates in the natural vegetation do indicate a marked influence of herbivory on the population (de Ruyter van Steveninck \& Bree$\operatorname{man} 1987$ ).

Moreover, high consumption of Lobophora variegata in reef communities where a $L$. variegata population is lacking does not necessarily imply that herbivory is the only cause for the species' absence in these zones. Other factors may restrict the possibility of $L$. variegata to survive and grow in these communities. To test for this possibility, long-term survival experiments were set up which showed that $L$. variegata could indeed survive and grow in these communities if in a situation of reduced herbivory (Fig. 2C, D). Moreover, growth rates in and outside cages were similar (Table 3), whereas half-lives of $L$. variegata blades were much higher inside than outside cages (Table 2) resulting in significantly larger blades inside cages (Fig. 3). These experiments clearly demonstrate the importance of grazing in restricting $L$. variegata to deep water and are in accordance with the occurrence of L. variegata at shallower depths only in situations with reduced grazing (e.g. in damselfish territories). They also provide evidence for the effect of herbivory on existing $L$. variegata communities. The high turnover rates of $L$. variegata blades in natural populations (half-lives of 9 to $39 \mathrm{~d}$; de Ruyter van Steveninck \& Breeman 1987) thus can be attributed to high grazing pressure which, in turn, limits blade size. This is in accordance with the observation that, as compared with temperate regions, the tropics are characterized by smaller algae, as a consequence of grazing (Gaines \& Lubchenco 1982)

Herbivorous fishes and sea urchins are generally held responsible for the inconspicuousness of algal vegetation on coral reefs (Ogden \& Lobel 1978, Borowitzka 1981, Gaines \& Lubchenco 1982, Littler \& Littler 1984), but there is some discussion of the relative importance of both groups of grazers (Hay 1984b). The spread of Lobophora variegata after Diadema antillarum mortality (de Ruyter van Steveninck \& Bak 1986, de Ruyter van Steveninck \& Breeman 1987) and the observed decrease in grazing pressure (Fig. 1 \& 2) would suggest that $D$. antillarum was the most important grazer on $L$. variegata on the coral reef of Curaçao before its extinction. Although it is difficult to assess the exact proportion of $L$. variegata consumed by fishes and urchins, there is evidence that, even before $D$. antillarum mortality, fish grazing was quantitatively more important. For example, the high consumption observed at B1 $35 \mathrm{~m}$ depth (Fig. 2 A) must be attributed to fish grazing, as hardly any $D$. antillarum occurred at that depth. Also, the large difference in half-lives and blade sizes in caged and non-caged $L$. variegata found in the December 1984 experiments (Table 2; Fig. 3) cannot have been caused by $D$. antillarum grazing, as D. antillarum had not re-established at B1 by that time (Bak 1985, de Ruyter van Steveninck pers. obs.).

These observations could be explained as follows: a decrease in diversity of herbivores generally should result in an increase in the probability that a given plant will escape herbivory (Gaines \& Lubchenco 1982). After Diadema antillarum mortality, algal abundance increased (de Ruyter van Steveninck \& Bak 1986) providing herbivorous fish with a larger supply of food, resulting in decreased grazing on any particular species, e.g. L. variegata (Fig, 1). After about 6 mo, a new equilibrium level in algal production and herbivory had been reached (de Ruyter van Steveninck \& Bak 1986, de Ruyter van Steveninck \& Breeman 1987).

Changes in algal community structure and diversity after exclosure or removal of Diadema antillarum have been documented by Sammarco et al. (1974), Carpenter (1981, 1985), Sammarco (1982), Hay \& Taylor (1985) and Liddell \& Ohlhorst (1986). In addition to a general reduction in grazing pressure, there may be another important effect of $D$. antillarum mortality. The grazing of echinoids is a very systematic scraping of the surface, which completely removes large areas of algae (Dart 1972, Sammarco 1980) and possibly germlings and sporelings of otherwise avoided macroalgae (Carpenter 1981). When parrotfish graze, a significant part of the algae remains untouched and these remnants can continue to grow (Borowitzka 1981). For Lobophora variegata this is illustrated in Fig. 7. In addition parrotfish have been observed to spill fragments when 
Fig. 7. Lobophora variegata. Grazing losses of transplants exposed to (A) grazing by fishes and sea urchins, and (B) fish grazing only. White: initial blade size; black: blade size after $96 \mathrm{~h}$ incubation
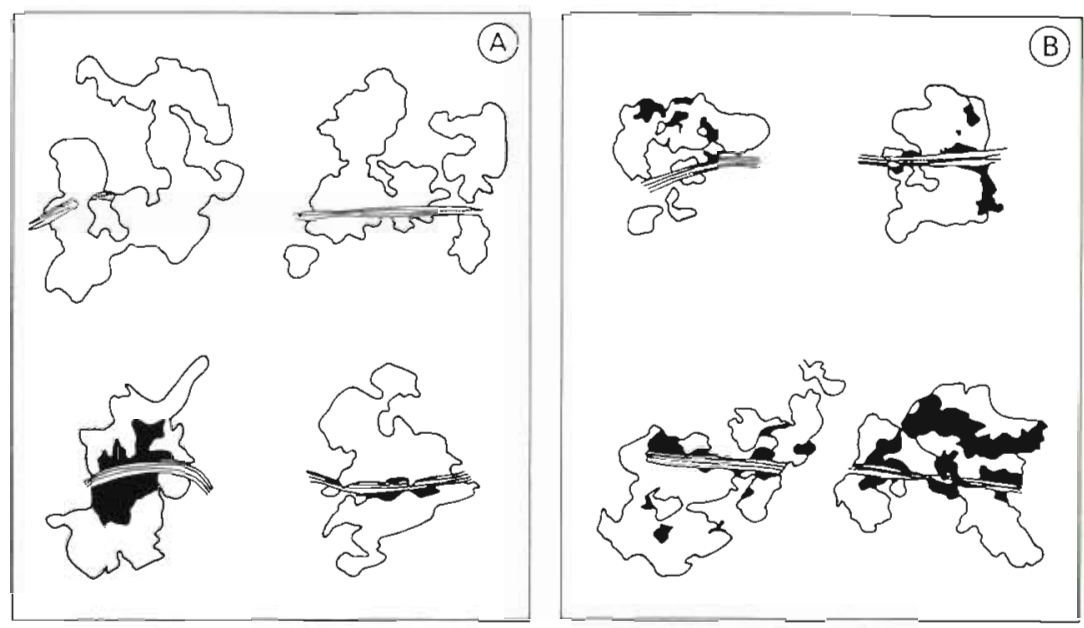

grazing on L. variegata (Hans Zomer pers, obs.), and these fragments possibly settle and start to regrow (de Ruyter van Steveninck pers. obs.). These phenomena may be particularly important in view of the limited dispersal potential of $L$. variegata by means of spores. Vegetative propagation seems to surpass sexual reproduction, a common phenomenon in perennial algae (Vadas 1979), which was also reported for L. variegata by Peckol \& Searles (1983) in North Carolina. In the present study, it was shown that dispersal and spread of $L$. variegata will occur mainly from existing $L$. variegata patches and does not reach over any considerable distance (Fig. 5 \& 6; Table 4). Relatively short dispersal ranges have also been found in other large brown algae (Anderson \& North 1966, Dayton 1973, Paine 1979, Amsler \& Searles 1980, Deysher \& Norton 1982). The limited dispersal potential of $L$. variegata, as observed in the present study, can explain the fact that, although following $D$. antillarum mortality, L. variegata has expanded to somewhat shallower depths (de Ruyter van Steveninck \& Breeman 1987), it has not become a conspicuous component at ca $12 \mathrm{~m}$ depth. The continued significant influence of fish grazing on $L$. variegata (manifested in the high turnover rates) will in turn further decrease successful settlement of $L$. variegata and thus prohibit dominance of this common macroalga at shallower depths in the coral reef of Curaçao.

Acknowledgements. We thank the director and staff of the Caribbean Marine Biological Institute, Curaçao, for working facilities and especially O. Frans, F. Isabella and A. Tiel for diving assistance. The short-term grazing experiments were carried out by Hans Zomer (supported by the 'Melchior Treub Fonds') and Marian Doom. Prof. Dr C. van den Hoek critically read the manuscript: this is gratefully acknowledged. The first author was supported by a grant of the Netherlands Foundation for the Advancement of Tropical Research (WOTRO) No. W84-201.

\section{LITERATURE CITED}

Amsler, C. D., Searles, R. B. (1980). Vertical distribution of seaweed spores in a water column offshore of North Carolina. J. Phycol. 16: 617-619

Anderson, E. K., North, W. J. (1966). In situ studies of spore production and dispersal in the giant kelp Macrocystis. In: Young, E. G., McLachlan, J. L. (ed.) Proc. 5th Int. Seaweed Symp. Pergamon Press, Oxford, p. 73-86

Bak, R. P. M. (1985). Recruitment patterns and mass mortalities in the sea urchin Diadema antillarum. Proc. 5th Int. Coral Reef Congr. Tahiti, Vol. 5: 267-272

Bak, R. P. M., Carpay, M. J. E., Ruyter van Steveninck, E. D. de (1984). Densities of the sea urchin Diadema antillarum before and after mass mortalities on the coral reefs of Curaçao. Mar. Ecol. Prog. Ser 17: 105-108

Borowitzka, M. A. (1981). Algae and grazing in coral reef ecosystems. Endeavour, N. S. 5: 99-106

Brawley, S. H., Adey, W. H. (1977). Territorial behavior of threespot damselfish (Eupomacentrus planifrons) increases reef algal biomass and productivity. Environ. Biol. Fish. 2: 45-51

Carpenter, R. C. (1981). Grazing by Diadema antillarum (Philippi) and its effects on the benthic algal community. J. mar. Res. 39: 749-765

Carpenter, R. C. (1985). Sea urchin mass-mortality: effects on reef algal abundance, species composition, and metabolism and other coral reef herbivores. Proc. 5th Int. Coral Reef Congr. Tahiti, Vol. 4: 53-60

Dart, J. K. G. (1972). Echinoids, algal lawn and coral recolonization. Nature, Lond. 239: 50-51

Dayton, P. K. (1973). Dispersion, dispersal and persistence of the annual intertidal alga Postelsia palmaeformis Ruprecht. Ecology 54: 433-438

Deysher, L., Norton, T. A. (1982). Dispersal and colonization in Sargassum muticum (Yendo) Fensholt. J. exp. mar. Biol. Ecol. 56: 179-195

Earle, S A. (1972). The influence of herbivores on the marine plants of Great Lameshur Bay, with an annotated list of plants. In: Colette, B. B., Earle, S. A. (ed.) Results of the Tektite Program: ecology of coral reef fishes. Natural History Museum, Los Angeles County, Sci. Bull. 14: 17-44

Gaines, S. D., Lubchenco, J. (1982). A unified approach to marine plant-herbivore interactions. II. Biogeography. A. Rev. Ecol Syst. 13: 111-138 
Harper, J. L. (1977). Population biology of plants. Academic Press, London

Hay, M. E. (1981a). Herbivory, algal distribution, and the maintenance of between-habitat diversity on a tropical fringing reef. Am. Nat. 118: 520-540

Hay, M. E. (1981b). Spatial patterns of grazing intensity on a Caribbean barrier reef: herbivory and algal distribution. Aquat. Bot. 11: 97-109

Hay, M. E. (1984a). Predictable spatial escapes from herbivory: how do these affect the evolution of herbivore resistance in tropical marine communities? Oecologia (Berl.) 64 : $396-407$

Hay, M. E. (1984b). Patterns of fish and urchin grazing on Caribbean coral reefs: are previous results typical? Ecology $65: 446-454$

Hay, M. E., Taylor, P. R. (1985). Competition between herbivorous fishes and urchins on Caribbean reefs. Oecologia (Berl.) 65: 591-598

Hoek, C. van den, Breeman, A. M., Bak, R. P. M., van Buurt, G. (1978). The distribution of algae, corals and gorgonians in relation to depth, light attenuation, water movement and grazing pressure in the fringing coral reef of Curaçao, Netherlands Antilles. Aquat. Bot. 5: 1-46

Hoek, C. van den, Cortel-Breeman, A. M., Wanders, J. B. W. (1975). Algal zonation in the fringing coral reef of Curaçao, Netherlands Antilles, in relation to zonation of corals and gorgonians. Aquat. Bot. 1: 269-308

Lewis, S. M. (1985). Herbivory on coral reefs: algal susceptibility to herbivorous fishes. Oecologia (Berl.) 65: 370-375

Liddell, W. D., Ohlhorst, S. L. (1986). Changes in benthic community composition following the mass mortality of Diadema at Jamaica. J. exp. mar Biol. Ecol. 95: 271-278

Littler, M. M., Littler, D. S. \{1980\}. The evolution of thallus form and survival strategies in benthic marine macroalgae: field and laboratory tests of a functional form model. Am. Nat. 116: 25-44

Littler, M. M., Littler, D. S. (1984). Models of tropical reef biogenesis: the contribution of algae. In: Round, F. E., Chapman, D. J. (ed.) Progress in phycological research, Vol. 3. Biopress Ltd., Bristol, p. 323-364

Littler, M. M., Littler, D. S., Taylor, P. R. (1983a). Evolutionary strategies in a tropical barrier reef system: functional-form groups of marine macroalgae. J. Phycol. 19: 229-237

Littler, M. M., Taylor, P. R., Littler, D. S. (1983b). Algal resistance to herbivory on a Caribbean barrier reef. Coral Reefs 2: $111-118$

Lubchenco, J., Gaines, S. D. (1981). A unified approach to marine plant-herbivore interactions. I. Populations and communities. A. Rev. Ecol. Syst. 12: 405-437

Morrison, D. (1984). Mass mortality of Diadema antillarum on a Jamaican coral reef: effect on the algal community. Advances in Reef Science, R.S.M.A.S., Miami, p. 85-86

Morrison, D. (1986). Antiherbivore chemical defense in coral reef algae: effectiveness against different herbivore functional groups. ASLO-PSA Meeting. Univ. of Rhode Island, Kingston, Rhode Island, p. 90

Norris, J. N., Fenical, W. (1982). Chemical defense in tropical marine algae. In: Rützler, K., Macintyre, I. G. (ed.) The Atlantic Barrier Reef ecosystem at Carrie Bow Cay, Belize Smithson. Contr. mar. Sci. 12: 417-431

Ogden, J. C., Lobel, P. S. (1978). The role of herbivorous fishes and urchins in coral reef communities. Environ. Biol. Fish 3: $49-63$

Paine, R. T. (1979). Disaster, catastrophe, and local persistence of the sea palm Postelsia palmaeformis. Science 205 $685-687$

Paul, V J., Hay, M. E. (1986). Seaweed susceptibility to herbivory: chemical and morphological correlates. Mar. Ecol. Prog. Ser. 33: 255-264

Peckol, P., Searles, R. B. (1983). Effects of seasonality and disturbance on population development in a Carolina continental shelf community. Bull mar. Sci. 33: 67-86

Randall, J. E. (1961). Overgrazing of algae by herbivorous marine fishes. Ecology 42: 812

Ruyter van Steveninck, E. D. de, Bak, R. P. M. (1986). Changes in abundance of coral-reef bottom components related to mass mortality of the sea urchin Diadema antillarum. Mar. Ecol. Prog. Ser. 34: 87-94

Ruyter van Steveninck, E. D. de, Breeman, A. M. (1987). Deep water vegetations of Lobophora variegata (Phaeophyceae) in the coral reef of Curaçao: population dynamics in relation to mass mortality of the sea urchin Diadema antillarum. Mar. Ecol. Prog. Ser. 36: 81-90

Sammarco, P. W. (1980). Diadema and its relationship to coral spat mortality: grazing, competition, and biological disturbance. J. exp. mar Biol. Ecol. 45: 245-272

Sammarco, P. W. (1982). Effects of grazing by Diadema antillarum Philippi (Echinodermata: Echinoidea) on algal diversity and community structure. J. exp. mar Biol. Ecol. 65: 83-105

Sammarco, P. W., Levinton, J. S., Ogden, J. C. (1974). Grazing and control of coral reef community structure by Diadema antillarum Philippi (Echinodermata: Echinoidea): a preliminary study. J. mar. Res. 32: 47-53

Vadas, R. L. (1979). Seaweeds: an overview; ecological and economic importance. Experientia 35: 429-432

Wanders, J. B. W. (1977). The role of benthic algae in the shallow reef of Curaçao (Neth. Ant.). III. The significance of grazing. Aquat. Bot. 3: 357-390 